\title{
Consumer Decision Making Style - Male Versus Female: A Study on Chattogram City, Bangladesh
}

\author{
Mohammad Toufiqur Rahman ${ }^{1}$ \\ ${ }^{1}$ Department of Business Administration, International Islamic University Chittagong., Bangladesh \\ Correspondence: Mohammad Toufiqur Rahman, Assistant Professor, Department of Business Administration, \\ International Islamic University Chittagong., Bangladesh.
}

Received: March 7, 2019

doi:10.20849/ajsss.v4i2.603
Accepted: May 3, 2019

Online Published: June 28, 2019

URL: https://doi.org/10.20849/ajsss.v4i2.603

\begin{abstract}
Genders play an important role to influence an individual's buying behavior activities all the time and it acts almost the same in any other region or cultures. This study has been conducted to identify whether there is any differences exist or not according to males' or females' decision making style. The questionnaire has been set by using Consumer Style Inventory (CSI) approaches $(\alpha=0.895)$ to collect data from 133 respondents of Chattogram city, Bangladesh. The CSI has been used to identify consumer decision making style with its eight factors and 37 items. By analyzing the data it has been found that there is no significant difference in between male and female regarding their decision making style. As this study is limited to Chattogram city only, so the study has a broader scope to do further research by accommodating with more cities or countries that are culturally diversified.
\end{abstract}

Keywords: male, female, decision making style, consumer behavior, CSI

\section{Introduction}

In marketing research, consumer behavior is always a vital issue. It is impossible to do business without consumer and no benefit can be made. In this manner, numerous advertisers and analysts attempt to determine what factors affect consumers to purchase items or services. Solomon (2009) states that gender distinctiveness is a major factor of a consumer's self-conception. Gender can be defined as sexual identity. Both men and women also think they are not at odds with their cultures in the manner they act (speak) or devour (dress). But if the time changes, the culture changes, these gender roles will change by time over. In any case, it is very uncertain that the different gender will be consumed differently. Thus, many vendors have carried out a great deal of research on gender in order to see whether men and women are going to consume the same thing or difference. As per Zawawi, Wong, Busu, and Hamzah (2004) said that gender consists of standards between men and women that strengthen them both.

The social research regarding this topic has been done severally in various countries and regions. In these examinations, a few qualities observed to be comparative while others observed to be diverse at different nations “(Hafstrom Chae, \& Chung, 1992; Durvasula , Lysonski \& Andrews, 1993; Lysonski , Durvasula, \& Zotos, 1996; Fan \& Xiao, 1998; Hiu , Siu, Wang, \& Chang 2001; Walsh , Hennig-Thurau, Wayne-Mitchell, \& Wiedmann 2001; Tai, 2005)". Consumer styles for commodities and goods were investigated and conclude that styles can be defined as consumer properties in relation to commodity goods cannot be obtained (Bauer, Sauer, \& Beeker, 2002).

From the above discussion, it has been observed that many research has been conducted over male and female but after technology improvement with the social network, it is now a new issue to identify the decision-making style of today's generation. As today's generation is far far different from earlier, so it would be a new finding for the company to know their decision-making style and on the basis of that, they could rearrange their offers to attract both male and female to make their purchase decisions.

\section{Literature Review}

Consumer behavior usually defined as choosing, utilizing and discarding items of an individual or organizational products and services (Blyth, 2013). Genders play an important role, which incorporates purchase behavior, in the human habit (Fan \& Miao, 2012; Hasan, 2010; Seock \& Bailey, 2008). Three approaches have been used to 
identify the decision making styles of a consumer. First one is psychological graphic, the second one is based on the typology of a consumer, and lastly through consumer features. First approach to psychological / lifestyle concern the decision-making process regarding the psychological characteristics and lifestyle of the consumer (Lastovic, 1974; Darden \& Ashton, 1974). Second approach places consumers according to their shopping styles in general categories (Westbrook \& Black, 1985; Moschis, 1976). The third approach focuses on consumers specific rational and emotional guidelines related to decision making.

Sproles (1983) first identified the principal features and intellectual attributes of consumer decision-making. Later then Kendall and Sproles (1986) have developed an inventory of consumer styles that included 40 items. On the basis of CSI, the eight mental characteristics have been identified and analyzed to know the consumer decision-making style. They are perfectionism, brand awareness, recreation awareness, fashion awareness, price awareness, careless, confused by choice, habitual and brand loyal (Sproles, 1983b; Sproles \& Sproles, 1990). Men and women are interested in various products according to Mitchell and Walsh (2004), and their preferring and getting those products are not the same.

Men are likely to be specific, looking only for the object they wish (Meyers-Levy, 1989) while women were generally comprehensive, looking for plenty information and place exertion toward the item they need (Park, Yoon \& Lee, 2009). Male buying processes are only a mission and searching for information is part and only a small amount of information is required to complete the purchasing process. Females are essentially unique in relation to men. They considered buying process as a delight and the search for information look as a joy, along these lines they are they are ready to search for information as much as they can (Park et al. cited 2009). Women like to buy items by novel-style that is funny and appealing while men want to buy is a popular and costly branded item (Yang \& Wu, 2007). Consumer surveys are considered as assessment options for consumer purchase decisions. The decision-making process may be affected by consumer reviews, as already mentioned. It has also demonstrated that it affects women more than men (Bae \& Lee, 2011; Fan \& Miao, 2012).

The present youthful guys are increasingly associated with shopping (Dholokia, 1999) and once the products that are considered for females are now produced as male products such as cosmetics, skin care, and fashion journals. Another study indicates men's view regarding shopping process as no pleasant and unwanted (Dholokia 1999), take less time and usually don't take accountability for the purchase of clothing and food than women (Cox and Dittmar 1995; Miller 1998), have less interest and are less sensitive to their friends ' opinions, make quick and carefree decision-making (Shoaf, Scattone, Maureen, and Durairaj, 1995), make faster / reckless choices more frequently (Areni and Kiecker, 1993 ; Prince, 1993) and are more autonomous, more trustworthy, more internally driven, more competitive and ready to take hazards with cash in particular. This brings us to the idea that male buyer will have distinct decision-making characteristics from women. Even though customers have a comparatively coherent style of decision making (Sproles and Kendall, 1996), there has been a little study into the gender variations addressed in this article.

From the above discussion and research, the hypothesis for this research was determined:

Null Hypothesis: Ho: Consumers' decision-making styles are different in case of male and female.

Thus the main objective of this study is to identify either males' or females' decision-making styles are dissimilar or not.

\section{Methodology}

This study is based on a survey. The survey was conducted over 150 customers though finally 133 (75 male and 58 female) was selected based on their fulfillment of data on a questionnaire. The survey was from a different location in Chattogram city, Bangladesh through random sampling to analyze their decision making style for both male and female. Marketing graduate student was responsible to do the survey and they have collected data in the month of January and February 2019 by visiting the customers personally.

Out of 40 items from eight factors of CSI has been surveyed over 12 respondents as for pilot survey and finally, 37 items have been selected based on their validity. The questionnaire was based on five points Likert scale from strongly agree to strongly disagree. 


\subsection{Reliability Analysis}

Table 1. Reliability analysis

\begin{tabular}{ll}
\hline Reliability Statistics & \\
\hline Cronbach's Alpha & N of Items \\
\hline .895 & 37 \\
\hline
\end{tabular}

Pavot, Diener, Colvin, and Sandvik (1991) state that, when the value of Cronbach's Alpha is equal to 0.7 or over, the scale is measured as reliable. In this study, the Cronbach Alpha coefficient was 0.895 that indicate the internal consistency and reliability of the scale with our sample.

\section{Results and Discussion}

\subsection{Demographic Analysis}

Table 2. Demographic description of the sample

\begin{tabular}{llllll}
\hline Demographic Variables & Frequency & Percentage & Demographic Variables & Frequency & Percentage \\
\cline { 2 - 3 } & $\mathbf{f}$ & $\mathbf{\%}$ & & $\mathbf{f}$ & $\mathbf{\%}$ \\
\hline Age & 45 & 33.8 & HSC & 12 & 9.0 \\
\hline Less than 30 & 78 & 58.6 & Bachelor's degree & 37 & 27.8 \\
\hline $30-45$ & 10 & 7.5 & Master's degree & 84 & 63.2 \\
\hline $46-61$ & & & Gender & & \\
\hline Occupation & 75 & 56.4 & Male & 75 & 56.4 \\
\hline Service holder & 14 & 10.5 & Female & 58 & 43.6 \\
\hline Business man & 30 & 22.6 & & & 100.0 \\
\hline House wife & 14 & 10.5 & Total & 133 & \\
\hline Student & & & & & \\
\hline
\end{tabular}

From the demographic analysis, we see that the most of the respondents were from the age group 30-45 years $(58.9 \%)$, service holder (56.4\%) and master's degree holders (63.2\%).

\subsection{T-Test}

Table 3. T-Test

\begin{tabular}{llllll}
\hline \multirow{2}{*}{ Items } & Means & \multicolumn{3}{l}{ Std. Deviation } & 2-tailed \\
\cline { 2 - 5 } & Male & Female & Male & Female & \\
\hline Factor-1: Brand Consciousness & & & & & \\
\hline Shopping is not a pleasant activity & 1.65 & 1.59 & .762 & .773 & .618 \\
\hline Shopping is very enjoyable to me & 2.92 & 3.14 & 1.160 & 1.146 & .282 \\
\hline I enjoy shopping just for fun & 2.36 & 2.45 & .981 & 1.029 & .615 \\
\hline Shopping in different stores is a waste of time & 2.99 & 3.36 & 1.097 & 1.195 & .062 \\
\hline $\begin{array}{l}\text { I spend little time deciding on the products and } \\
\text { brands I buy }\end{array}$ & 2.17 & 2.45 & .891 & 1.172 & .127 \\
\hline
\end{tabular}

\section{Factor-2 : Perfectionism}

\begin{tabular}{llllll}
\hline In general, I usually try to buy the best overall & 2.33 & 2.40 & 1.004 & 1.042 & .724
\end{tabular}


quality

I make a special effort to choose the very best quality products

1.68

$1.78 \quad .70$

.701

.796

.462

I have very high standards and expectations for the products I buy

$\begin{array}{lllll}2.11 & 2.24 & .967 & .961 & .426\end{array}$

\begin{tabular}{llllll}
\hline Getting good quality is very important to me & 2.63 & 2.88 & 1.112 & 1.186 & .209 \\
\hline $\begin{array}{l}\text { A product doesn't have to be exactly what I } \\
\text { want or the best on the market to satisfy me }\end{array}$ & 2.73 & 3.07 & 1.031 & 1.074 & .070 \\
\hline $\begin{array}{l}\text { I really don't give my purchases much thought } \\
\text { or care }\end{array}$ & 2.61 & 2.97 & 1.138 & 1.154 & .081 \\
\hline $\begin{array}{l}\text { I usually shop quickly, buying the first product } \\
\text { or brand that seems }\end{array}$ & 3.16 & 3.33 & 1.175 & 1.205 & .421 \\
\hline
\end{tabular}

\begin{tabular}{|c|c|c|c|c|c|}
\hline \multicolumn{6}{|l|}{ Factor-3: Brand Consciousness } \\
\hline $\begin{array}{l}\text { The most advertised brands are usually good } \\
\text { choices }\end{array}$ & 2.83 & 2.62 & .991 & 1.073 & .254 \\
\hline I prefer buying the best selling brands & 2.56 & 2.48 & 1.093 & 1.143 & .693 \\
\hline $\begin{array}{l}\text { The higher the price of the product, the better } \\
\text { the quality }\end{array}$ & 2.92 & 3.14 & 1.160 & 1.146 & .282 \\
\hline $\begin{array}{l}\text { Good quality department stores and specialty } \\
\text { stores offer the best }\end{array}$ & 2.99 & 3.36 & 1.097 & 1.195 & .062 \\
\hline I usually buy well-known brands & 2.33 & 2.40 & 1.004 & 1.042 & .724 \\
\hline \multicolumn{6}{|l|}{ Factor-4: Fashion Consciousness } \\
\hline $\begin{array}{l}\text { I keep my wardrobe up to date with the } \\
\text { changing fashions }\end{array}$ & 2.63 & 2.88 & 1.112 & 1.186 & .209 \\
\hline $\begin{array}{l}\text { I usually have at least one outfit of the newest } \\
\text { style }\end{array}$ & 2.73 & 3.07 & 1.031 & 1.074 & .070 \\
\hline $\begin{array}{l}\text { Fashionable, attractive styling is very important } \\
\text { to me }\end{array}$ & 3.16 & 3.33 & 1.175 & 1.205 & .421 \\
\hline $\begin{array}{l}\text { For variety I shop in different stores and buy } \\
\text { different brands }\end{array}$ & 2.56 & 2.48 & 1.093 & 1.143 & .693 \\
\hline It's fun to buy something new and exciting & 1.65 & 1.59 & .762 & .773 & .618 \\
\hline \multicolumn{6}{|l|}{ Factor-5: Confused Over choice } \\
\hline $\begin{array}{l}\text { There are so many brands to choose from that I } \\
\text { often feel confused }\end{array}$ & 2.36 & 2.45 & .981 & 1.029 & .615 \\
\hline $\begin{array}{l}\text { I am confused by all the information on } \\
\text { different products }\end{array}$ & 2.17 & 2.45 & .891 & 1.172 & .127 \\
\hline $\begin{array}{l}\text { The more I learn about products, the harder it } \\
\text { seems to choose the best }\end{array}$ & 1.68 & 1.78 & .701 & .796 & .462 \\
\hline $\begin{array}{l}\text { Sometimes it's hard to decide in which stores to } \\
\text { shop }\end{array}$ & 2.63 & 2.88 & 1.112 & 1.186 & .209 \\
\hline \multicolumn{6}{|l|}{ Factor-6: Price Consciousness } \\
\hline $\begin{array}{l}\text { I look very carefully to find the best value for } \\
\text { money }\end{array}$ & 2.61 & 2.97 & 1.138 & 1.154 & .081 \\
\hline I usually buy the lower priced products & 2.83 & 2.62 & .991 & 1.073 & .254 \\
\hline I buy as much as possible at sale price & 2.36 & 2.45 & .981 & 1.029 & .615 \\
\hline
\end{tabular}




\begin{tabular}{llllll}
\hline Factor-7: Careless & & & & & \\
\hline I frequently purchase on impulse & 2.33 & 2.40 & 1.004 & 1.042 & .724 \\
\hline I often make purchases I later wish I had not & 2.63 & 2.88 & 1.112 & 1.186 & .209 \\
\hline $\begin{array}{l}\text { I should spend more time deciding on the } \\
\text { products I buy }\end{array}$ & 3.16 & 3.33 & 1.175 & 1.205 & .421 \\
\hline I carefully watch how much I spend & 2.92 & 3.14 & 1.160 & 1.146 & .282 \\
\hline Factor-8: Habitual and Brand Loyal & & & & & 1.172 \\
\hline I have favorite brands I buy every time & 2.17 & 2.45 & .891 & .127 \\
\hline When I find a brand I like, I buy it regularly & 2.11 & 2.24 & .967 & .961 & .426 \\
\hline I go to the same stores each time I shop & 2.61 & 2.97 & 1.138 & 1.154 & .081 \\
\hline I regularly change the brands I buy & 2.83 & 2.62 & .991 & 1.073 & .254 \\
\hline 95\% Confidence Interval of the Difference & & & & & \\
\hline
\end{tabular}

T-Test was used to see whether there are any differences exists or not over male and female and by the analyzing of the mean value, we see that there were not many meaningful differences. In all the 8 factors covering 37 items, surprisingly it has been seen that there are no differences in decision making style of both male and female.

According to Cohen (1988), If the value in the significant (2-tailed) is equal or less than .05, then there is a significant difference in the mean score and if the value is higher than .05 there is no significant difference between the two groups. As in my study, it has been seen that all of my significant value is much higher than .05 that states that the mean scores between the groups are not significantly different. So, the null hypothesis $\mathbf{H o}$ has been rejected.

\section{Conclusion and Limitations}

In conclusion, gender always plays a significant role in their decision making style. They are the main factor that always affects their purchasing process. Consumer decision making style still is a big concern for the researchers and every time it reveals with some new issues that are always interesting. In this studies we have also found out the interesting issues that male and female have the same decision-making style whereas several studies have been found the opposite. From the study, we can also say that today's generation is not acting like their previous generations especially in their decision-making style.

This study has been conducted over Chattogram City only, like many cities of Bangladesh and as well as in other countries, there is huge cultural diversity and there may be different consumer decision making style exists. As Bangladesh has very low cultural diversity compared to other countries, therefore, the study has a broader scope to do further research by accommodating more cities in the different countries of the world. This study also has a limitation that it only considered the consumer shopping style but not the product categories. So, for further research in more countries and regions with their respective culture, this study may be used.

\section{References}

Areni, C. S., \& Kiecker, P. (1993). Gender differences in motivation: some implications for manipulating task-related involvement. In C. J. Arnold (Ed.), Gender consumer behavior (pp.30-43). Salt Lake City, Utah: University of Utah Printing Service.

Bae, S., \& Lee, T. (2011). Gender differences in consumers' perception of online consumer reviews. Electronic Commerce Research, 11, 201-214.

Bauer, H., Sauer, N. E., \& Beeker, C. (2002). Product-Independent Consumer Decision-Making Styles: Do They Really Exist?. American Marketing Association Conference Proceedings, 13, 174-175.

Blythe, J. (2013). Consumer behaviour (2nd ed.). London: SAGE Publication.

Campbell, C. (1997). Shopping, pleasure and the sex war. In P. Falk, \& C. Campbell (Eds.), The shopping experience?. London: Sage.

Cathy, B., \& Vincent-Wayne, M. (2006). Male versus Female Consumer Decision Making Styles. Journal of Business Research, 59, 1297-1300.

Cohen, J. (1988). Statistical power analysis for the behavioral sciences. Hillsdale, NJ: Erlbaum. 
Cox, J., \& Dittmar, H. (1995). The functions of clothes and clothing (dis)satisfaction: a gender analysis among British students. Journal of Consumer Policy, 18, 237-265.

Darden, R. W., \& Ashton, D. (1974). Psychographic Profiles at Patronage Preference Groups. Journal of Retailing, 50, 99-112.

Dholakia, R. R. (1999). Going shopping: key determinants of shopping behaviors and motivations. International Journal of Retail \& Distribution Management, 27(4), 154-165.

Durvasula, S., Lysonski, S., \& Andrews, C. (1993). Cross-Culturel Generalizability of a Scale for Profiling Consumers' Decision-Making Styles. The Journal of Consumer Affairs, 27(1), 55-65.

Fan, J. Y., \& Xiao, J. J. (1998). Consumer Decision-Making Styles of Young-Adult Chinese. Journal of Consumer Affairs, 32(2), 275-94.

Fan, Y. W., \& Miao, Y. F. (2012). Effect of electronic word-of-mouth on consumer purchasing intention: The perspective of gender differences. International Journal of Electronic Business Management, 10(3), 175-181.

Hafstrom J. L., Chae, J. S., \& Chung, Y. S. (1992). Consumer Decision-Making Styles: Comparison between United States and Korean Young Consumers. Journal of Consumer Affairs, 26(1), 146-158.

Hasan, B. (2010). Exploring gender differences in online shopping attitude. Computers in Human Behavior, 26, 597-601.

Hiu, A. S. Y., Siu, N. Y. M., Wang, C. C. L., \& Chang, L. M. K. (2001). An Investigation of Decision-Making Styles of Consumers in China. Journal of Consumer Affairs, 35(2), 326-345.

Lastovicka, L. J. (1982). On the Validation of Lifestyle Traits: A Review and Illustration. Journal of Marketing Research, 19(1), 126-138.

Lim, P. L., \& Yazdanifard, R. (2014). Does Gender Play A Role In Online Consumer Behavior?. Global Journal of Management and Business Research: E Marketing, 14(7), 49-56.

Lysonski, S., Durvasula, S., \& Zotos, Y. (1996). Consumer Decision-Making Styles: A Multi-Country Investigation. European Journal of Marketing, 30(12), 10-27.

Meyers-Levy, J. (1989). The Influence of Sex Roles on Judgment. Journal of Consumer Research, 14, 522-530.

Miller, D. A. (1998). Theory of shopping. Oxford: Blackwell Publishers Ltd.

Mitchell, V. W., \& Walsh, G. (2004). Gender Differences in German Consumer Decision-Making Styles. Journal of Consumer Behavior, 3(4), 331-346.

Moschis, P. G. (1976). Shopping Orientations and Consumer Uses of Information. Journal of Retailing, 52(2), 61-93.

Park, J. Y., Yoon, Y. S., \& Lee, B. T. (2009). The effect of gender and product categories on consumer online information search. Advances in Consumer Research, 36, 362-366.

Pavot, W., Diener, E., Colvin, C. R., \& Sandvik, E. (1991). Further validation of the Satisfaction with Life scale: Evidence for the cross method convergence of wellbeing measures. Journal of Personality Assessment, 57, 149-161.

Prince, M. (1993). Women, men and money styles. Journal of Economic Psychology, 14, 175-182.

Seock, Y. K., \& Bailey, L. R. (2008). The influence of college students' shopping orientations and gender differences on online information searches and purchase behaviors. International Journal of Consumer Studies, 32, 113-121.

Sevtap, U., \& Aysel, E. (2008). The Role of Gender Differences in Determining the Style of Consumer Decision-Making. Bogazici Journal, 22(1-2), 89-106.

Shim, S. (1996). Adolescent consumer decision making styles: the consumer socialisation perspective. Psychology and Marketing, 13(6), 547-569.

Shoaf, F. R., Scattone, J., Morrin, M., \& Maheswaran, D. (1995). Gender differences in adolescent compulsive consumption. Advances in Consumer Research, 22, 500-504.

Solomon, M. (2009) Consumer Behavior: Buying, Having, and Being (8th ed.). New Jersey, Upper Saddle River: Pearson Education Inc. 
Sproles, B. G. (1983a). Conceptualization and Measurement of Optimal Consumer Decision-Making. The Journal of Consumer Affairs, 17(2), 421-438.

Sproles, E. K., \& Sproles, B. G. (1990). Consumer Decision-Making Styles as a Function of Individual Learning Styles. The Journal of Consumer Affairs, 24(1), 134-147.

Sproles, G. B., \& Kendall, E. L. (1986). A Methodology for Profiling Consumers' Decision-Making Styles. The Journal of Consumer Affairs, 20(2), 267-279.

Tai, S. H. C. (2005). Shopping Styles of Working Chinese Females. Journal of Retailing and Consumer Services, 12, 191-203.

Walsh, G., Hennig-Thurau, T., Wayne-Mitchell, V., \& Wiedmann, K. P. (2001). Consumers' Decision-Making Style as a Basis for Market Segmentation. Journal of Measurement and Analysis for Marketing, 10(2), 117-131.

Westbrook, A. R., \& Black, W. C. R. (1985). A Motivation-Based Shoppen Typology. Spring Journal of Retailing, 61(1), 78-103.

Yang, C., \& Wu, C. C. (2007). Gender and internet consumers' decision-making. Cyber Psychology \& Behavior, 10(1), 86-91.

Zawawi, D., Wong, F. Y., Busu, R., \& Hamzah, Z. L., (2004). The effects of sex role orientation on family purchase decision making in Malaysia. Journal of Consumer Marketing, 21(6), 381-390.

\section{Copyrights}

Copyright for this article is retained by the author(s), with first publication rights granted to the journal.

This is an open-access article distributed under the terms and conditions of the Creative Commons Attribution license (http://creativecommons.org/licenses/by/4.0/). 